\title{
Compilation of Spatial Models in Improving the Performance of Maintenance of Irrigation Area Networks in Purwodadi and Brati Districts, Grobogan
}

\author{
Soedarsono $^{1 *}$ and Selvia Agustina ${ }^{1}$ \\ ${ }^{I}$ Civil Engineering Study Program, Sultan Agung Islamic University, Jl. Raya Kaligawe km.4 Semarang \\ * Corresponding author: soedarsono@unissula.ac.id
}

(Received: 20 ${ }^{\text {th }}$ January 2021; Accepted: $29^{\text {th }}$ April 2021)

\begin{abstract}
The Grobogan Regency Government, apart from constructing and maintaining weir buildings and dams that function to divide irrigation water, also continues to strive in developing the Secondary Irrigation Area Network. However, until now the handling of the construction and maintenance of the Irrigation Network carried out by the Department of Public Works and Spatial Planning of Grobogan Regency has not been able to be carried out optimally because there are several obstacles faced, including limited geographic / spatial-based data and information that is accurate as a tool for know the location of the Irrigation Network infrastructure and the supporting buildings for the Irrigation Network. The purpose of this research is to implement a Geographical Information System (GIS) application using the ArcGis program, to compile an information system in the form of a data base for the Irrigation Area network and to determine the priority for the maintenance of the Irrigation Area network using the following parameters: how much area is the Irrigation Area network irrigated, how long is the irrigation area canal damage and how much it costs to maintain the irrigation network The inventory data of the irrigation area network is obtained from the Irrigation and Raw Water sector of the PUPR Service of Grobogan Regency, this data is in the form of existing irrigation area network data, As-built Drawing images from the implementation results and photos of the location of the irrigation area network. The data will be used for data base and materials for monitoring and evaluation in preparing maintenance programs for the following year.
\end{abstract}

Keywords: Maintenance of irrigation; Irrigation area; Geographical Information System (GIS)

\section{Introduction}

The need for irrigation water as one of the supporters of the success of crop yields in Grobogan Regency, damaged Irrigation Area networks can affect the availability of water needed for crop needs in the fields. So that it requires data on information on irrigation area networks and data on conditions of irrigation area networks.

Based on the decision of the Regent of Grobogan Number 610/520/2016 concerning the second amendment to the decision of the Regent of Grobogan number 610/338/2015 regarding the status of irrigation and river areas whose management is the responsibility and authority of the Grobogan Regency Government. Given the large number of irrigation area networks that must be handled by the Grobogan Regency Government, both development and maintenance, while the funds available for handling are very limited, it is necessary to prioritize the handling of the Grobogan Regency Irrigation Network so that the budget allocation is effective for the 
development and development of Grobogan Regency so that it can maximize agricultural product.

Limited data and information, especially those based on geography / spatial as a tool used to find out the location of a secondary irrigation area network along with the supporting buildings in the irrigation system and the area of rice fields flowed by the irrigation network is an obstacle faced by the Department of Work General and Spatial Planning of Grobogan Regency. The absence of a sufficiently clear guideline in terms of differentiating the classification of irrigation networks based on their functions, especially those differentiating between secondary irrigation networks and tertiary irrigation networks, so that in the implementation of irrigation network management there is often an overlap between the Agriculture Service and the Irrigation Sector, the Public Works and Spatial Planning Office. Grobogan Regency,

\section{Literature review}

According to the Regulation of the Minister of Public Works and Public Housing No. 14 / PRT / M / 2015 concerning Criteria and Determination of the Status of Irrigation Areas, irrigation is an effort to provide, regulate and dispose of water to support agricultural productivity, the types of which include surface irrigation, swamp irrigation, underground water irrigation, pump irrigation, and pond irrigation. . The irrigation system includes irrigation infrastructure, irrigation water, irrigation management, irrigation management institutions, and human resources.

\section{Irrigation Area}

The meaning of irrigation area (DI) is a unit of agricultural land that gets water from an irrigation network. The irrigation network itself is a building, a channel and a complementary structure which is a unit needed for the provision, use, distribution, provision and disposal of irrigation water. In a Government Regulation, irrigation networks are classified into three types, namely:

\section{Irrigation Area Classification}

In Irrigation Planning Standards KP - 01, irrigation networks are classified into three types, namely:

1) Primary irrigation network, namely irrigation network consisting of main building, primary / main channel, drain channel, dividing building, tapping building, tapping building, and complementary buildings.

2) Secondary irrigation networks are irrigation networks consisting of secondary channels, dumping channels, dividing structures, tapping buildings, tapping buildings, and complementary structures.

3) Tertiary irrigation networks, namely irrigation networks that have a function as infrastructure for irrigation water services into a tertiary plot consisting of tertiary channels, quaternary channels and dumping channels, tertiary boxes, quarter boxes, and complementary buildings.

\section{Irrigation Network}

In the Irrigation Planning Criteria (KP-01) according to the manner of arrangement and completeness of the facilities, irrigation networks are classified into 3 (three) types, namely (1) simple irrigation networks, (2) semi-technical irrigation networks and (3) technical irrigation networks. How to arrange and complete the facilities, the irrigation network is classified into: 
1) Simple Irrigation Network

This network has the characteristics of taking buildings and other structures that are temporary, non-permanent and the provision of water as needed cannot be determined exactly how much is needed but only in the form of an estimate.

2) Semi Technical Irrigation Network

It is an irrigation network that has a permanent structure, but there are no complementary structures to distribute water regularly.

3) Technical Irrigation Network

The principle of the technical irrigation network is the separation between drainage channels and irrigation channels. This can be interpreted either, namely that the drainage channel and irrigation channel are in accordance with their respective functions. The network already has permanent retrieval buildings and complementary buildings. The irrigated agricultural area has been divided into compartments so that the required water needs can really be adjusted according to what is needed.

\section{Geographical Information System}

Geographic Information System (GIS) or Geographic Information System (GIS) is a system designed to capture, store, analyze, manipulate, organize and display all types of geographic data (Irwansah, 2013).

\section{Subsystem in GIS}

The advantages of using a digital system GIS are:

- Reduce mistakes made by humans,

- Able to analyze more accurate data,

- Merge overlaps to one network,

- Improve data by paying attention to statistical data, environmental changes, and visible areas.

Geographical Information System is supported by 3 sub-systems, namely geodatabase, geoprocessing, and geovisualization, which have their respective functions. (Prahasta, 2001)

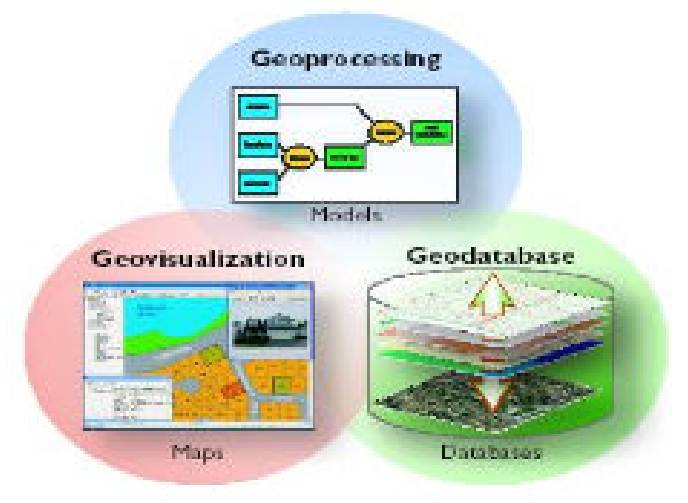

Fig. 1. GIS compiler sub system

\section{Research methods}

\section{Research sites}

The research location chosen was Grobogan Regency with 2 Districts (Purwodadi and Brati Districts) which only included the Secondary Irrigation Area Network under the authority of Grobogan Regency without the provincial and central authority Irrigation Network. 


\section{Research Stages}

The stages to be carried out in this research activity include data collection, survey and field investigation, as well as data analysis with the creation of a Geographical Information System (GIS).

\section{Stage I: Preparation}

1) Collecting maps and data of irrigation area networks in accordance with the classification of functions and authority of the Irrigation Division of the Public Works and Spatial Planning Office of Grobogan Regency.

2) Collection of As built drawings from the results of project work implementation from 2018 to 2020 .

\section{Phase II: Survey and Updating Data}

1) Conduct a field survey,

2) Tracing the classification of irrigation area networks,

3) Tracking the existing geometrical conditions of the irrigation area network which includes the coordinate points of the main building, the length of the irrigation channel, the area being flowed and other data using GPS.

4) Field measurements on several irrigation networks.

5) Weighting using the scoring method

\section{Data collection technique}

Data collection techniques used in this study are primary data collection and secondary data. Primary data is data obtained by conducting direct surveys in the field. The primary data obtained in this study are geometrical data of the Irrigation Area using GPS to collect the coordinates of the location of the Irrigation Area which include: main building points, length of irrigation canals, width of irrigation canals, area of irrigation area, and type data collection. irrigation structures (soil, masonry, masonry face, concrete) and irrigation water intake models (pumps, weirs or springs). Primary data obtained in this study include:

1) Photo documentation of existing in each irrigation area

2) History of the year of development / work of the irrigation area

3) The data on the percentage of damage to the Irrigation Area Network

Secondary data, namely supporting data obtained from a related agency. Secondary data obtained in this study include:

1) Java mosaic thematic map data: source of the Geospatial Information Agency (BIG) 2020.

2) Thematic map data for the Grobogan Regency area: source from Bappeda Grobogan Regency Regional Regulation on Spatial Planning for Grobogan Regency in 2020.

3) Data on Rice Fields in Grobogan Regency: source from the Geospatial Information Agency (BIG) in 2020.

4) Regional map data of each District in Grobogan Regency: source from the National Land Agency for Grobogan Regency in 2020.

5) List data of Irrigation Area Networks along with area, channel length and channel width in Grobogan Regency: source from the Public Works and Spatial Planning Office of Grobogan Regency in 2020.

6) Data on unit prices for materials and wages in 2020: source from the Public Works and Spatial Planning Office of Grobogan Regency in 2020.

7) Data on the Irrigation Area Network project work carried out in 2018 to 2020: source from the Public Works and Spatial Planning Office of Grobogan Regency in 2020. 


\section{Analysis and Discussion}

\section{Parameter Weighting Process for Priority Determination}

The weighting for determining the priority of irrigation network maintenance is determined by three parameters, namely:

\section{Irrigation Network Damage}

Assessment of parameters on damage to irrigation networks in determining priority is based on an assessment of the functional condition of the irrigation network, namely the length of the damaged canal. With this determination, which will be used in the stage of determining the priority of irrigation network development and selecting the type of work handling as well as determining the estimated budget costs that will be used for the preparation of the proposed program for the annual irrigation network development activity plan.

The classification of damage to the physical condition of the irrigation network according to PERMEN PUPR number 12 / PRT / M / 2015 concerning Exploitation and Maintenance of Irrigation Network is divided into 3 (three) classes. Assessment on the research weighting of each class is given a value of 1 to 3 based on the level of damage, damage to irrigation networks has the highest weight value of 3 , so the handling is prioritized. The classification of damage to irrigation networks and their weighting can be seen in Table 1.

Table 1. Classification of Irrigation Network Conditions, Classification and Weighting

\begin{tabular}{ccc}
\hline Damage & Damage Class & Weight \\
\hline$\leq 20 \%$ & Light Damage & 1 \\
\hline $21-40 \%$ & Medium Damage & 2 \\
\hline$>40 \%$ & Heavy Damage & 3 \\
\hline
\end{tabular}

Source: Permen PUPR number 12 / PRT / M / 2015

\section{Irrigation Network Area Parameters}

Area classification is known from the area of the survey results as outlined in the arc gis application where the area of each irrigation network is different. Weighted area is given a value of 1 to 3, where the irrigation network that has the widest area gets the highest value because the yields to be obtained are greater. While the smallest area will get the lowest weight value. The stage of making an area classification is as follows:

- $\quad$ Average area $=\frac{6560 \mathrm{ha}}{59 \mathrm{DI}}=111,186 \mathrm{ha}$

- $\quad$ Then the Class Interval Division 50 ha $=\frac{111,186 h a}{3}=37,06$

So that the area classification table can be arranged as follows:

Table 2. Area Classification

\begin{tabular}{ccc}
\hline Area & Class & Weight \\
\hline$\leq 50$ ha & Small & 1 \\
\hline $51-100$ ha & Moderate & 2 \\
\hline$>100$ ha & Big & 3 \\
\hline
\end{tabular}

Source: Analysis Results, 2020

\section{The Need for Priority Development Implementation Costs}

The determination of this weight value follows the division of the work package for the implementation of government procurement of goods and services according to the Presidential 
Regulation of the Republic of Indonesia Number 16 of 2018. In determining the priority weight, this is different from the level of damage and the area to be drained, so for low cost values a large value is given. while high costs are given a small weight value. This is done so that the maintenance of the irrigation network can be carried out evenly in the damaged irrigation area.

Table 3. Classification of Cost Requirements

\begin{tabular}{cccc}
\hline Cost Requirement & Type of Procurement & Class & Weight \\
\hline Max 100,000,000 & Direct Procurement & Small & 3 \\
\hline $100,000,000 \mathrm{~s} / \mathrm{d} 200,000,000$ & Direct Procurement & Moderate & 2 \\
\hline Above 200,000,000 & Auction & Big & 1 \\
\hline
\end{tabular}

Source: Per press No. 16 of 2018, Government Procurement of Goods / Services

\section{Determination of Priority for Maintenance of Irrigation Networks}

Based on the results of the weighting of the three predetermined parameters, the sum of weights (Damage Weight + Area Weight + Cost Needed Weight) is carried out and the results of the summation are classified into 3 (three) recommended classes for irrigation network maintenance using Geographic Information System (GIS) analysis through layer "Bangunan_Utama" $\rightarrow$ properties $\rightarrow$ categories $\rightarrow$ value field: priority $\rightarrow$ add all values $\rightarrow$ ok. Classification of recommendations for determining priority for irrigation network maintenance based on total weights can be seen in Table 5.5. below and the results of priority recommendations for each irrigation area network can be seen in Table 4.

Table 4. Priority Determination Classification

\begin{tabular}{cc}
\hline Total Weights & Class of Recommendation \\
\hline $3-5$ & Postponed \\
\hline 6 & Soon \\
\hline $7-9$ & Urgent \\
\hline
\end{tabular}

Source: Analysis Results, 2020

\section{Schematic of Irrigation Area Network Maintenance Management System}

Based on a series of processes that have been carried out starting from compiling an information system / data base to the results of analysis in determining the priority of irrigation area network maintenance which is carried out using the Geographical Information System (GIS) method, as a whole it can produce a process in compiling a Maintenance Management System concept. Irrigation Area Network in Grobogan Regency. A schematic table of the stages of implementing the activities and the results obtained can be seen in Table 5 below:

Table 5. Stages of Irrigation Network Maintenance Management

\begin{tabular}{|c|c|c|c|c|}
\hline Stage & & Activities & & The results achieved \\
\hline Data Bank & a) & $\begin{array}{l}\text { Irrigation network inventory } \\
\text { data collection }\end{array}$ & a) & $\begin{array}{l}\text { Irrigation area network } \\
\text { classification data }\end{array}$ \\
\hline (data base) & b) & $\begin{array}{l}\text { Identifying conditions and } \\
\text { problems of irrigation } \\
\text { networks in the field (survey) }\end{array}$ & c) & $\begin{array}{l}\text { List of irrigation area networks, } \\
\text { area, channel length and } \\
\text { problems in the field }\end{array}$ \\
\hline $\begin{array}{l}\text { General Planning } \\
\text { (Planning) }\end{array}$ & a) & $\begin{array}{l}\text { Types of treatment for } \\
\text { damage to irrigation networks }\end{array}$ & a) & The types of materials used \\
\hline $\begin{array}{l}\text { Programming } \\
\text { (Programming) }\end{array}$ & a) & $\begin{array}{l}\text { Irrigation network } \\
\text { maintenance priority scale } \\
\text { (parameter analysis) }\end{array}$ & b) & $\begin{array}{l}\text { List of irrigation schemes to be } \\
\text { addressed (in order of priority) }\end{array}$ \\
\hline
\end{tabular}




\begin{tabular}{lllll}
\hline \multicolumn{1}{c}{ Stage } & \multicolumn{1}{c}{ Activities } & \multicolumn{1}{c}{ The results achieved } \\
\hline & a) & Estimated cost requirements & c) & Unit price, volume and RAB \\
\cline { 2 - 5 } Preparation & b) & Design plans & d) & DED and contracts \\
\hline & c) & $\begin{array}{l}\text { Schedule of handling } \\
\text { implementation }\end{array}$ & e) & $\begin{array}{l}\text { Year of implementation of the } \\
\text { activity program }\end{array}$ \\
\hline $\begin{array}{l}\text { Implementation and } \\
\begin{array}{l}\text { Evaluation of Activities } \\
\text { (Operation and } \\
\text { Evaluation) }\end{array}\end{array}$ & a) & Execution of physical work & f) & $\begin{array}{l}\text { Selection of irrigation area } \\
\text { network }\end{array}$ \\
\hline
\end{tabular}

Source: Analysis Results, 2020

\section{Model Builder}

The builder model for merging the rice fields of Grobogan Regency and the District Borders of Grobogan Regency is as follows:

1) Open the arc catalog $\rightarrow$ right click $\rightarrow$ add toolbox $\rightarrow$ new toolbox $\rightarrow$ save with the name: Irrigation Network Management.

2) Right-click the Irrigation Network Management toolbox $\rightarrow$ new $\rightarrow$ model $\rightarrow$ rename it with the name: Compound Layer Model.

3) Right-click the Irrigation Network Management toolbox $\rightarrow$ new $\rightarrow$ model $\rightarrow$ rename with the name: Prioritization Model.

4) Right click on model builder $\rightarrow$ edit $\rightarrow$ Enter the layers to be merged, namely: Sawah_Kab_Grobogan and Batas_Kec_Kab_Grobogan.

5) Also include the toolbox used in data processing, namely the merge toolbox and the layer by attribute select toolbox.

6) toolbox merge: management tools $\rightarrow$ general $\rightarrow$ merge.

7) toolbox select layer by attribute: management tools $\rightarrow$ layer and table views $\rightarrow$ select layer by attribute.

8) Click run to run the model builder process.

The following is a builder model for merging layers and determining the priority of the irrigation area network development in Grobogan Regency with a Geographical Information System (GIS) using the Arc GIS 10.5 application.

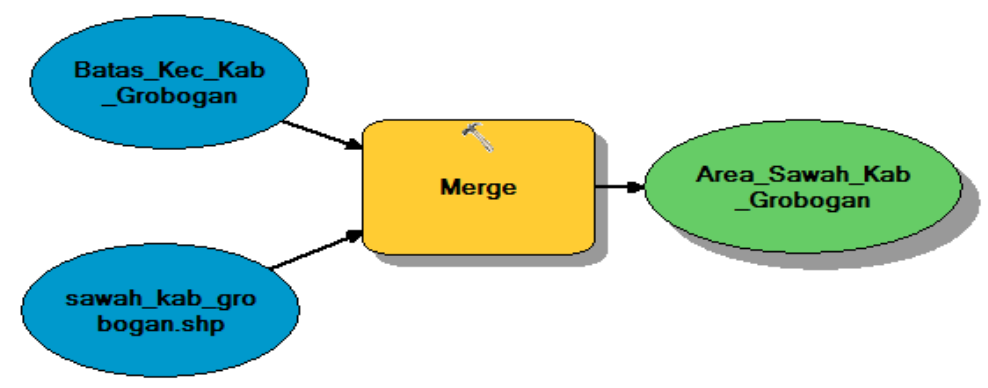

Figure 2 Layer Merge Builder Model

\section{Conclusion}

Based on the results of the analysis and discussion of the above research, the following conclusions can be drawn:

1) The information system / digital data base using GIS collateral can be compiled in the form of an inventory of the Irrigation Area Network data of the authority of the Grobogan 
Regency Government, especially the Grobogan Regency Public Works and Spatial Planning Office, from 2 Districts (Purwodadi and Brati) that have been researched to produce a number of irrigation area networks based on surveys currently.

2) By using the GIS method of all processes used, the concept of a management system for the maintenance of irrigation area networks is obtained which includes the following stages: preparation of a data bank (data base). $\rightarrow$ irrigation network inventory data collection $\rightarrow$ irrigation area network classification data; general planning (planning) $\rightarrow$ types of handling damage to irrigation networks $\rightarrow$ the types of materials used; programming (programming) $\rightarrow$ parameter analysis $\rightarrow$ list of DI networks that must be handled; preparation for implementation $\rightarrow$ cost requirements, design and implementation schedule $\rightarrow$ volume and RAB; implementation and evaluation of activities (operation and evaluation) $\rightarrow$ implementation and updating of data $\rightarrow$ job evaluation and updating the data base.

\section{Acknowledgments}

On this occasion, the researchers would like to thank LPPM UNISSULA for funding this research.

\section{References}

[1] ArcGis version 10.5 (2018), Data Processing and Research Map Making (in Indonesian).

[2] Agrianto, Ferry et al. (2016), Evaluation of Urban Drainage Network Based on Geographic Information System (GIS) in Sumenep City, Journal of Civil Eng., Universitas Sebelas Maret (in Indonesian).

[3] Balai Pemetaan dan Informasi Infrastruktur (2018), Technical consultation module for the preparation of Irrigation Area Map 2018, Jakarta: Center for Data and Information Technology Secretariat General of the Ministry of Public Works and Public Housing (in Indonesian).

[4] Ernawati, Yulianti, Liza, Suryana, Eko (2014), Geographic Information System Development of Irrigation Network in Bengkulu Province Based on Website Using Google Map, Bengkulu: Journal of Media Infotama Vol. 10(2) (in Indonesian).

[5] Global Mapper 16 (2018), Converting Kml Files to Shapefiles (Shp) (in Indonesian).

[6] Google Earth (2018), Coordinate Data Processing (in Indonesian).

[7] Hernawan, Ryan et al. (2013), GIS-Based Irrigation Asset Management Decision Support System Modeling, Surabaya: Proc. of National Seminar of Technology Management XVIII, ISBN: 978-602-97491-7-5, ITS (in Indonesian).

[8] Hutauruk, Jeremia Kevin Ronio et al. (2016), Subak Land Information System Based on Remote Sensing and Geographic Information System in Denpasar City, E-Jurnal Agroekoteknolgi Tropika. Vol.5(3) (in Indonesian).

[9] Irwansyah, Edy (2013), Geographic Information Systems: Basic Principles and Application Development, Yogyakarta : Digibooks (in Indonesian).

[10] Kandari, Aminudin Mane and Safuan, La Ode (2013), Evaluation of Land Suitability for the Development of Robusta Coffee (Coffea Canephora) Based on Climate Data Analysis Using Geographic Information System Applications, Journal of Agroteknos, Vol.3(1), pp.8-13 (in Indonesian).

[11] Raharjo, Puguh Dwi (2010), Remote Sensing Techniques and Geographic Information Systems for Drought Potential Identification, Journal of Makara, Technology Series, Vol. 14(2), pp.97-105 (in Indonesian).

[12] Setiawati, Danar, Linsa dan Hariyanto, Teguh (2011), Use of Web-Based Geographic Information System for Formation of Water Base Map Prototype (Case Study: Sidoarjo 
Regency), Journal of Scientific, Study Program of Geomatica Technique, FTSP-ITS (in Indonesian).

[13] Sofyan, Mirza, Isya, M. and Anggraini, Renni (2017), Utilization of Geographic Information System (GIS) for Priority Road Handling in Aceh Besar District, Journal of Civil Eng., Universitas Syiah Kuala (in Indonesian).

[14] Susanto, Kharis and Khotimah (2016), Information System for Mapping Agricultural Land and Harvest Commodities in Kudus Regency, Journal of Informatika, Vol.10(2) (in Indonesian). 